\title{
Basic Knowledge and Reasoning Process in the Art Creation
}

\author{
Bambang Sunarto \\ Ethnomusicology Department, Indonesian Arts Institute, Surakarta, Indonesia \\ Email: bsunarto432@gmail.com
}

Received 25 February 2015; accepted 8 May 2015; published 13 May 2015

Copyright (C) 2015 by author and Scientific Research Publishing Inc.

This work is licensed under the Creative Commons Attribution International License (CC BY). http://creativecommons.org/licenses/by/4.0/

c) (i) Open Access

\begin{abstract}
Basically, process in the art creation is supported by three pillars of existence, namely 1) activity, 2) method, and 3) knowledge. In the application of activities, methods, and knowledge are always accompanied by the reasoning of the creators of art. Reasoning is used to obtain formulation of practical knowledge, productive knowledge, and theoretical knowledge of an object. The creators in directing its attention to the target of creation use a set of logically interrelated concepts, supported by reasoning in varied models. Substance of reasoning contains of several elements, i.e., confidence, the will to work, models, concepts, methods of concept application and the artwork. The mastery of reasoning and the material elements of reasoning are important issues in the development of pillars of artwork creation.
\end{abstract}

\section{Keywords}

\section{Art Creation, Knowledge, Object, Reasoning}

\section{Introduction}

The essence of science is inseparable unity of three interconnected elements. Those are: 1) the process of an activity (Warfield, 1976: p. 42), 2) carried out using the method (Kemeny, 1961: p. 175), 3) to produce a set of systematic knowledge (Lachman, 1969: p. 13). Essentially, the nature of art is not much different from the nature of science. Art is also inseparable unity of activities, methods, and knowledge. There is no work of art as well as science created without the support of activities, methods, and knowledge. It shows that science and art are in common of their supporting pillars.

Science and art, in enforcing their structural reality, as a distinctive characteristic or their existential trait, are supported by the three same entities. Thus, science and art are in fact similar organisms. Therefore, the creation of art as a field of study may include science discipline as well as the art discipline. Both of them have regularity 
and elements which need to be previously determined, prescribed conduct.

This article is not about whether the art creation is a discipline of science or a discipline of art. Both disciplines are not in contrast; the art creation as a science discipline and as the art disciplines are supported by the same pillars, namely the activities, methods, and knowledge. It will focus on elaborating pillars of knowledge in the art creation. Limitations of space and time are not possible for this article to elaborate more about the pillars of activity and method as the backbone of the art creation, both as science and as an art.

The discussion on the pillars of knowledge is very important since the discipline of art creation is not isolated from the discipline of knowledge. In fact, knowledge is the most basic pillars which enable the artist to create his/her works. Knowledge is the basis to perform the activity and to select the method, so an artist can resolve the will in creating a work of art.

Aristotle states that knowledge can be divided into three types, namely 1) the practical knowledge (praktike), 2) productive knowledge (poiteike), and 3) theoretical knowledge (the oretike) (Peter, 1970: p. 60). In certain fields, especially in the formal sciences, science deals only with theoretical knowledge alone. In the humanities, social sciences, natural sciences, and religion science, they can not escape from the three types of knowledge. This is also for the discipline of art creation. Thus, the pillars of knowledge for the establishment of the existence of the art creation are practical knowledge, productive knowledge, and theoretical knowledge.

The art creation as a discipline can be thought of as the accumulation of knowledges that are connected logically, rationally, coherently, systematically and generally. The knowledges contain the principles, rules, concepts and/or theories of art creation. It is such a knowledge which makes the art creation regarded to contain a theoretical knowledge.

The accumulation of knowledge can be an accumulated practical knowledge alone, productive knowledge alone, or theoretical knowledge alone. However, it may be anaccumulation of two or three types of the knowledges. It shows that the science of art creation is also a collection of facts and various integral propositions, of which application brings theoretical knowledge into practice of art creation skill. Skill of art creation can be comprised of practical skill, productive skill, and theoretical thinking skill.

The art creation of art as an art discipline, another side of the science of art creation, is the creativity and the result of the operation of the art creation science. Art creation, which is the result of creativity manifested by the competence of art creator, namely the mastery of creator on the science of art creation. An elementary competence that must be achieved by a a creator in carrying out the creativity of the art creation is a practical skill. The skill is necessary to enable a creator to reveal the values he/she believes and considers important to be shared publicly. This is due to the nature of art creation as an activity to express the values, sharing the principles and ideal sense of beauty, goodness, and truth, makinguse of a complex structure of interdependent elements. However, to producea perfect art creation, a creator needs more than practical skill. A perfect art creation always requiresa support of the mastery of knowledge and practical skills and/or knowledge and productive skills, which may be also supported by theoretical knowledge.

Knowledgesto master by the art creators in art creation activity include practical and theoretical knowledges. Practical knowledge will be complete as it accompanied by practical skills to support the activity of art making art. Practical knowledge is a prescriptive knowledge, its form is a competence to conduct activities for the purpose in order to achieve a specific meaning. Theoretical knowledge is knowledge of the results of contemplative, rational, abstract thinking and analysis of the relationship between elements in a fact, or relationships among the facts in a set of facts (Peter, 1970: p. 60).

Knowledge of art creation for artist can consist of 1) explicit knowledge, 2) tacit knowledge, and 3) implicit knowledge. Explicit knowledge is knowledge of a declarative form. Tacit knowledge is knowledge obtained from experience, not in the form of declarative. Implicit knowledge is knowledge that has not been in a declarative form, but it can be converted into a declarative form (Griffith et al., 2003: p. 267). The art creation as a discipline and as an art discipline requires mastery of all types of knowledge.

The art creation requires knowledge in the form of objects, methodology, forms ofpropositions, proposition contents used in the study of art creation. Mastery of the knowledge of all will be the means of study that focuses on the efforts of object processing. To that end, the following will discuss the necessary objects to exist in the discipline of art creation, both as a discipline and as an art disciplines.

Study of art creation can be done if itsbasic conditions are met. It absolutely requires a reasoning, namely the process of application of logic and/or pattern of abstract thinking in solving the problem or in determining the actions planned. The presence of reasoning within the framework of disciplines to study the art creation is do- 
minant. The presence of the reasoning in the frame of art disciplines in the study of art creation is not dominant, because it is possible that the artcreation is dominated by intuition and imagination. However, the reasoning in the frame of art disciplines to the study of the creation of art is necessary there. Reasoning remains important, especially in the study of the art creation of art in academic nature.

Understanding the reasoning that can be used to study an art creation can refer to the notion from Gazalba (1977: p. 147). This is necessary to establish the right knowledge. Reasoning is a right thinking along with the rules of law and terms of thought. A right knowledge is required for the world of art creation. Without a right knowledge, it is undoubtedly difficult to produce scientific work as well as meaningful works of art.

Reasoning is logics. There are two kinds of logics. The first is formal logic, the rules of thinking which requires three stages of thinking that must be undertaken, namely 1) understanding, 2) judgment, and 3) statement. The second is the material logics. The second logics is the rules to think focusing on the material or the thought content ona form of thought. To see the validity of thinking correctly, Sunarto (2010: p. 42) argues that there is anevent to inevitably occur, an encounter of the creator or a researcher and their specific objects. The event does occur in the process of artistic creation as well as in the implementation of scientific research. The relation of subject-object is the basic step to produce scientific work or work of art, as a result of the activity done using a method. Formation of understanding, decision, statement as a manifestation of thinking rule is through the meeting of the subject and his/her object, of which elements are as follows (Figure 1).

The three elements are source, means, and procedures in scientific research and the creation of artworks. The object and the subject is the source well as a means for the research and artistic creation. Their encounter is the procedures of art creation. The relationship between the subject and the object causes the process of thinking in the subject. The object is the source and the major means of the establishment of scientific works and artworks. Without an object as the target of subject intention, scientific works or artworks art will never be born.

Based on the meeting or relationships, there arise the process of thinking in the subject. The process of thinking is subject's mental activity in driving reasoning to reach a scientific truth or artistic stability through the identification, categorization, the development of the definition, analysis, synthesis, and interpretation. It is an inner dialogue using abstract ideas whose reality is not a fictitious idea. It is is a kind of reasoning activity in creating decisions and statements as a manifestation of the action planning efforts. Process of thinking in the subject of researcher or art creator can be assumed as a diagram shown in the Figure 2.

Basically the object, the subject, and a meeting between the two are the main prerequisite of research activities or the creation of artworks.The meaning of an object, in this context, is everything, concrete and abstract, presented to the senses and/or to the consciousness of researcher or creator of art. It can be a variety of objects or events outside the subject or something considered to be outside the subject, which stimulate his/her awareness.It can be a thought content within subject that evokes a certain consciousness.

An understanding that develops in the subject is the existence of the subject him/herself, which contains all sorts of ideas that areaffirmed or denied by quality, relationships, characteristics, and properties. Thus, a growing understanding in the subject is nothing but the existence of researcher and creator of art to be a container to put relevant things in the form of awareness and quality, relationships, characteristics, and specific properties. All of them exists and is present in the subject as knowledge.

The meeting between subject and object is the convergence of a variety of things, either abstract objects or events or concrete objects or events, which are outside the subject as well as inside the subject, which stimulates the subject to be aware of the existence of the both. The meeting raised an inner experience in the subject. The inner experience for the subject researchers creates a desire to do perception and representation of the object in depth. It stimulates the development of thoughts, feelings, emotions and a certain semitotic desires to the existence of object. Thus, the relationship between the object and the subject in scientific research and in the art creation of art is an event or moment of the emergance ofthe semiotic symptoms in the subject. Semiotic symptoms in scientific research is an attempt of understanding of artistic symbols and their concepts contained therein. And

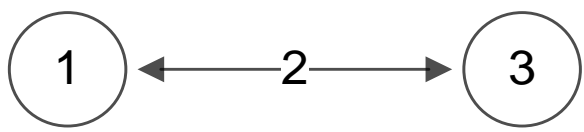

1: Object; 2: Meetings between the object to the subject; 3: Subject (cited from Sunarto, 2010: p. 39, 2013: p. 97)

Figure 1. Basic elements of scientific work/art work creation. 


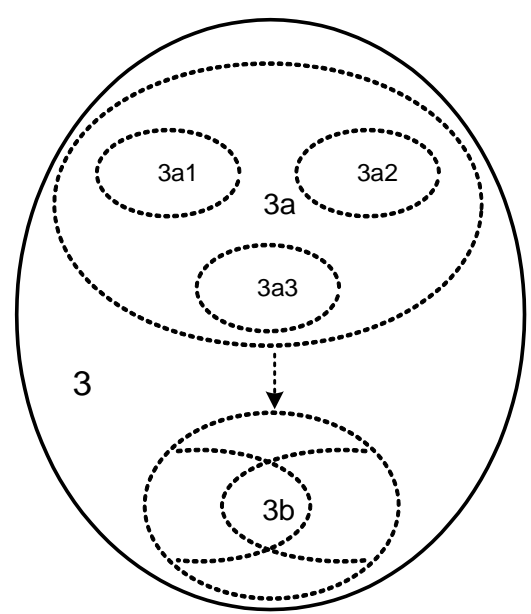

Note:

3. Subjekof researcher /art creatori

3a. Definition

3a1. Interpretation

3a2. Processing

3a3. Considering

3b. Finding/Decision

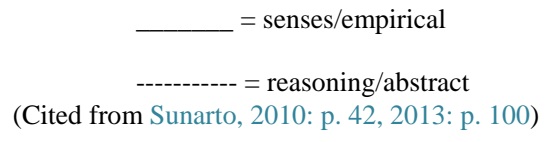

Figure 2. Activities of subject's thinking.

that in the art creation is an indication of the effort of development of the artistic symbols and their conception, to fulfill the function of sharing values presenting thoughts, feelings, emotions, and artistic desires of the subject.

Therefore, the existence of the object, the subject, and the meeting between the two are prerequisites for scientific research and for the art creation activity. The three have to be there in every activity of scientific research and the creation of works of art. If one of them is not present, then the activity of scientific research or artwork creative activity artwork will never start.

\section{Material and Formal Objects}

According to Friedel (1943: p. 16) and Houde \& Michael-Mullally (1960: pp. 31-33) every science always has a complete basic element in the form of 1) a material object, and 2) a formal object. The essence of art, as mentioned above, is no different from the nature of science. Therefore, the arts also have the same basic elements of its completeness, in the form of 1) a material object, and 2) a formal object.

Material object for science is a material that is reviewed, analyzed and studied by scientists in search of knowledge (Turner, 2004: p. 17). The material object of art is the material studied, analyzed, interpreted, and processed by an artist in creating his/her artwork. Formal object of science is the central focus of the central problem or goal of study as a scientist searches of knowledge (Turner, 2004: p. 17), as embodied in the thinking process of research subjects. Formal object of art is the goal of interpretation and objectives of art working of the world phenomena as the material object in the creation of art that manifests itself in the thinking process the art creator subject.

\subsection{Material Objects in the Study of Art Creation}

The material object in the art creation is a substance or material that can be studied, studied, analyzed or worked in research or art creation activities. Material object in the science of art creation is a worldwide phenomenon with regard to artistic activities in the creation of artworks. Material object in the activity of art creation is a wide variety of intrinsic or extrinsic values behind the world phenomena in the broadest sense, concrete and abstract, unfolded in the presence of awareness of the art creators.

The substance or material which may be a target of study is limited to the phenomenon of art creation done by art creators. But the target of working in the art creation is a world phenomenon in the broadest sense, both con- 
crete and abstract, which can be a sign of a meaning. The material of art creation is a wide range of phenomena that stimulate the emergence of a desire to represent thoughts, feelings, emotions and a certain semiotic desire over the object, particularlythe main desire of semiotics in order to produce the philosophical meaning of the sign system produced by art creators.

Again, material of art creation science is the phenomenon of art creator's creativity in producing works of art. The phenomenon of creativity in the art creation is how the creators produce artworks inworking the sign system. Signs are all things that imply the relationship ofsymbols, signals, icons, and indexes to its object (Jablonski, 2010: p. 36). Therefore, the material object of art is a phenomenon of art creator creativity in generating a system of signs with regard to the production and expression of artwork. The material of art is a reality that becomes the target, the central foci, the direction of mental strength intentionality of art creators. Material object of artwork creation are the various phenomena of the reality of the world outside of the selves of art creator, or the reality within them is positioned as something outside. The phenomenon includes a variety of things, both concrete and abstract, the material and the immaterial, in the form of natural objects and objects of artistic products, or abstract things such as concepts, theories, methods, techniques, and images about something.

Material object is the subject of science, related to the proposition that must be made about (Klubertanz, 1955: p. 4). Indeed, the material object in art is the subject of art. Its existence is always associated with the artistic propositions made by the art creators in anartwork.

\subsection{Formal Objects in the Study of Art Creation}

\subsubsection{Formal Object of Art Creation in the Discipline}

Formal object in the science of art creation is a means of thought for the development of artistic creation, which requires a set of logically interrelated concepts. A set of concepts projected by researchers to form a framework that serves to understand, interpret, and explain reality or problems faced by researchers of the artwork and art creation activities analyzed, studied, and learned. Fact or issue that needs to be understood, interpreted, and explained is a material object, which is realized in the form of things that exist as the essence and accidentals of the artwork. Its scopes, among others, are objects of the artistic product or concept, theory, methods, techniques, and images of somethingexposed in the awareness of the art creators.

A set of concept consists of several elements, which according to Ahimsa-Putra (2009: p. 2) is called a paradigm. Paradigm is the scope of the elements of scientist's thought to understand, explain and seek the truth of the fact or issue in a material object. These elements include 1) the basic assumptions, 2) values, 3) models, 4) the questions to be answered, 5) concepts, 6) the method, 7) methods of analysis, 8) the results of the analysis (theory), 9) scientific papers/ethnography (Ahimsa-Putra, 2008: p. 7).

In a scientific study, models, basic assumptions, and values can be stated explicitly, but they may also be stated implicitly. The questions or issues, concepts, research methods, methods of analysis, the results of the analysis, as well as the character and structure of knowledge generated should be stated explicitly. All elements in the construction of thought and their functional relationships can be used for building a construction of art creation science. The thought construction and the description of the functional relationships amongthe existing elements, can be seen in the Figure 3.

\subsubsection{Formal Object of Art Creation in Art Discipline}

In the arts disciplines, the attention focus of the art creation is factual and internal matters concerning practical problems in art production and expression. The art creation in the art discipline is concerned with how the art creator is supposed to process the sign system to express the meaning of artistic expression. It is a discipline containingpractical, tacit and implicit knowledges. Practical knowledge is prescriptive knowledge in the form of competence in conducting activities for the purpose of achieving a specific meaning. Tacit knowledge is knowledge gained from experience and is not in a declarative form. And the implicit is the knowledge that can be converted into a declarative.

The art creation is always grounded on the pillarsor principles idealized by the creator him/herself. The form of pillars is an "idealism" of art creator to express the artistic expression he or she creates. Based on the pillars he/she believes, each art creator surpasses various alternative values and artistic options in the process of artistic creation he/she does himself.

The pillars as the basis of performance of art creators in his/her working stand with the elements, as an 


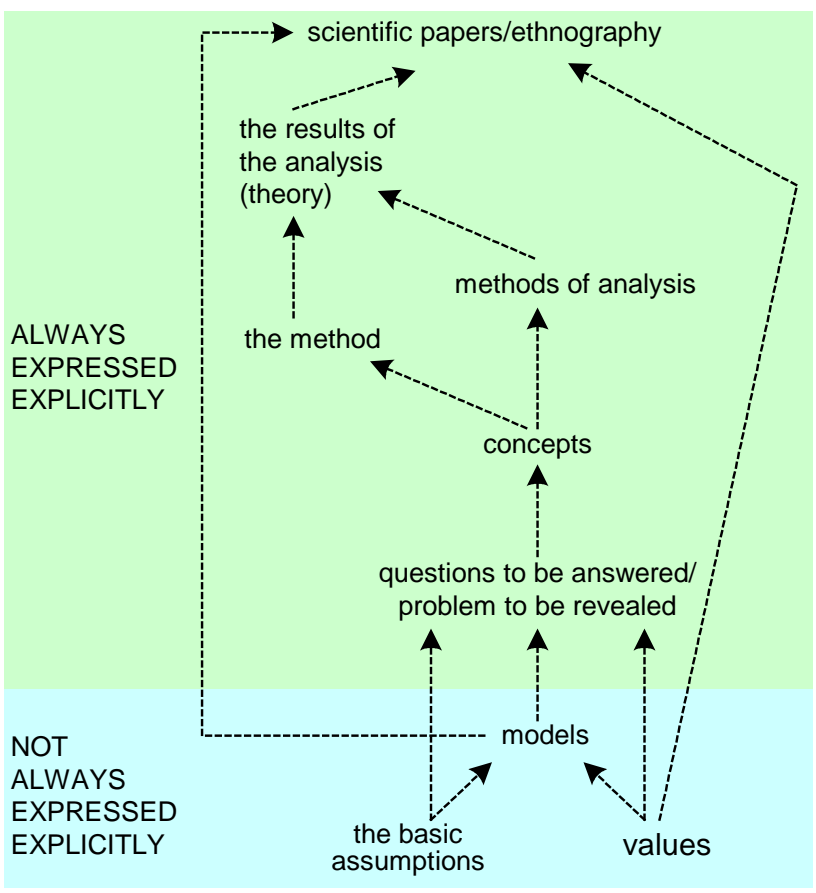

Figure 3. Elements of paradigm. Cited from the elements of paradigm in the socio-cultural science (Ahimsa-Putra, 2008: p. 7).

inseparable unity between reasoning and feeling. At least there are seven elements exist when the art creator builds his/her pillars in their working. Those elements are 1) beliefs, 2) will to work, 3) models, 4) the concept, 5) the method of applying the concept, 6) artwork (Sunarto, 2010: p. 35). To illustrate, the unitary elements of paradigm orpillarsin the art creation of art is as shown in Figure 4.

First, the art creator realizes that he has certain belief, functioned as a base or footing in the work. Beliefe is the intellectual and emotional agreement that object unfold in front of his/her consciousness can represent beauty, goodness, or truth. In the belief, itcontains knowledge of intrinsic and extrinsic values of an object. The agreement is an idea potential having pragmatic power to create artwork (Sunarto, 2010: pp. 35-53).

After realizing the belief he/she holds, an art creator begins to develop the will to work. It is an intention or desire to present the artistic conception to represent the values of the objects exposed in the presence of consciousness. Then, he/she develops a model of the work to be realized. The model is forms imagined. Its realization is an imaginative picture of the artistic shape or construction, a work embryo. Once the model is imaginatively developed, a creator builds a concept based on an imagined model. The essence of a concept is an explanation or a confirmation of the existence of the model, the manifestation of artistic value consciousness and an intellectual awareness of the art creator.

Method or way to realize a work in the art creation is developed after the idealized models and concepts have been formed. The method should follow the belief, the will to work, models, and concepts. The underlying belief of an art creator is a habit of mind, things evolving in mind, which makes the art creator has a feeling of confidence to do something. Therefore, the basic belief is the background of the efforts of creating artworks. The elements of pillars are among others, models and concepts, whichare imaginative reality as the direction and purpose of art creation.

Method as a procedure or process to achieve a goal of art creation includes 1) the method of concept development and 2) the method to realize the concept. The purpose of art creation is to realize models and concepts that are abstract, idealistic and semiotic to become a real empirical and semiotic reality.

The last element of (pillar) in the art creation is theartwork. It is a reality of empirical symbols, which can be understood as an existence equivalent to the ethnography or other works of thoughts products, like scientific papers. It is regarded to be equivalent because in the artwork contained logical relationships among variables, between elements, and between the symptoms, which constitutes the concern of art creator to be expressed empirically, symbolic, and semiotically. Their difference is only that the artwork is in the form of artistic 


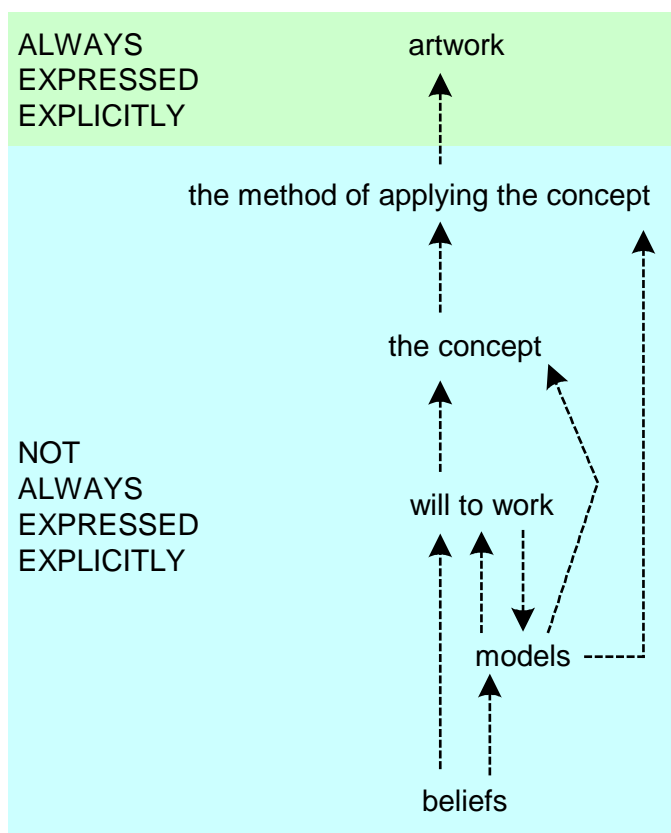

Figure 4. Elements and reasoning in the Pillars of art creation (Sunarto, 2014b: p. 72).

construction; meanwhile the ethnographic or scientific work is a textual elaboration of an object. However, both have a description and explanation of the potential relationships between variables, between elements and between the symptoms.

Ideally, a study of the art creation to the development of art disciplines should foster the development of each person involving in the study to have a self-awareness of each pillar he or she develops. It means growing ability of the subject to be the object for himself. In another word, the meaning is to be objective to see him/herself, particularly in developing the ideal principles in the art creation he/she initiates. Self-awareness is the competence to see the self as the others can see his/herself. Primarily in exploring the experience when he/she explores the artistic process, perception process, representation, development of thought, feeling, emotion, intuition, and desire in the reasoning process used to create the artwork.

Self-awareness is important because the reasoning in the art creation is not a single. That is the reasoning as illustrated in diagram 4 above is not the only one of thinking line for art creators. The reasoning process of the art creator can consist of several alternative possibilities. However, the elements of pillars involved in the thinking process of each artcreator in the works are the elements mentioned above, namely 1) beliefs, 2) will to work, 3) models, 4) the concept, 5) methods of concept, and 6) artwork.

\section{Self-Awareness in Developing Reasoning}

An art creator can develop reasoning in some alternative possibilities. The first reasoning can be developed by art creators as illustrated in the diagram 4 above. Both reasonings can be seen in the Figure 5 .

Reasoning in the second possibility starts from a belief of art creator about broad values. The belief can be either 1) instrumental values, 2) the utilitarian value, and 3) the value of wigati (significance) to bea humane orientation. Instrumental value is the value in a thing to produce the consequences or outcomes he/she desires (Bagus, 2005: p. 717). The utilitarian value is the useful value owned by a thing to fulfill a purpose, or it is useful in advancing the great virtues (Bagus, 2005: p. 719). The wigati value as humane orientation is the value considered to be meaningful or significant to the life survival, which is pursued by everyone or by certain individuals. All three entities of the valuesare beliefs that become the basis for developing the will to work. At this stage, the art creator already has the basic knowledge to work, i.e. knowledge about the values considered to be 1) a means to result in work, 2) useful for the fulfillment of the growth of virtues and/or truth, and 3) important in life, through the expression of beautiful forms. 


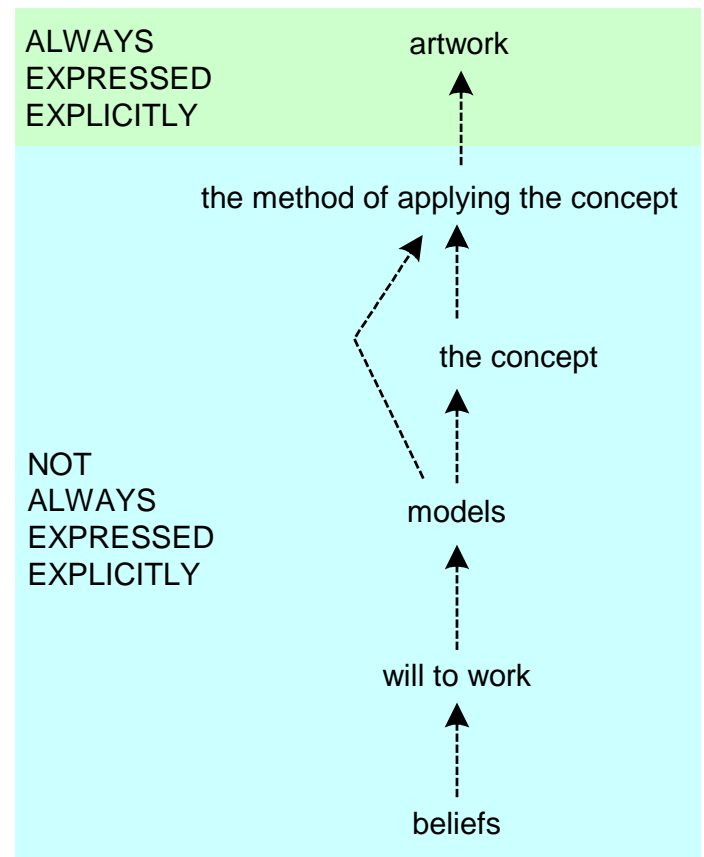

Figure 5. First possibility of reasoning inpillars of art creation (Sunarto, 2014b: p. 77).

After that, a process of intensive reasoning in the art creator, that is the effort to develop the model of work to be created. The models are the artistic forms imagined by the art creators; its realization is an imaginative picture of the artistic shape or construction as the embryo of anartwork. Based on these models, the art creator builds a concept, i.e. an explanation or a confirmation of the model existence, the manifestation of artistic awareness and intellectual consciousness of the art creator.

Art creator develops methods of applying models and concepts to realize the work he/she imagines. The development of method is made after he has significant knowledge about models and concepts that will be created. The method consists of practical ways of how to make the model and concept idealized in the imagination can be empirically realized. The empirical reality of the models and concepts is an artworks, havinga semiotic and/or symbolic nature. In the creation of art in general, the elements of faith, the will to work, models, concepts and methods developing in the creator's mind is never stated explicitly. He/she states them explicitly only his/her artwork, as a last estuary of the reasoning process he/she undertakes.

The third reasoning, which is different from the first and second reasoning above, can be developed by art creator through a process as illustrated in the Figure 6.

Like the reasoning in the first (diagram 4) and the second (diagram 5), the possibility of a third reasoning also starts from a belief art creator on the values. Their difference is in the fact that after having a belief, art creator is not instantly coming to a willing to work. The willonly appear after the creator develops his/her imagination to find models and concepts. The concept is also formulated after a model imagined is present in mind. Therefore, the will to work emerges strongly with the support of beliefs, models and concepts. At this stage, when the art creator has a will to work, he or shehasan adequate knowledge about the various paradigmatic aspects on the artwork to be created by him/herself.

Development of methods is made by orienting towards the application of models and concepts to realize the work imagined. Method is always developed after the art creator has a significant knowledge about the models and concepts of the work to create. Finally, the artwork will be materialized after the method developed is implemented in accordance with the concept and model imagined.

There are many possible reasonings that can be developed in building pillars for a creator as he/she creates an artwork. Not all of them can be described in this article due to the limited space to elaborate. It focuses on two most important reasonings in setting up pillars, i.e. 1) conventional reasoning in traditional art creation, and 2) contemporary reasoning in the contemporary art creation. 


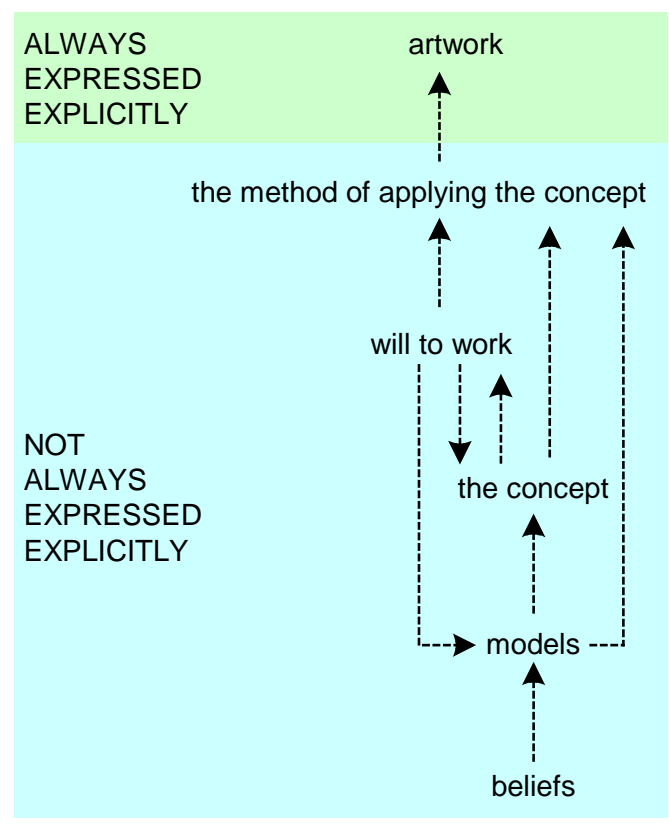

Figure 6. Second possibility in the pillars of art creation (Sunarto, 2014b: p. 79).

\subsection{Conventional Reasoning in Traditional Art Creation}

Reasoning in the pillars development for the creation of traditional arts are always grounded on and oriented to entrenchedartistic discourses. It works generallyamong traditional artists when creating artwork. It is extremely different from that in the creation of contemporary artworks. However, despite the differences, there are common elements shared in the pillars, i.e. beliefs, models, concepts, methods, will to work, andartwork.

The reasoning for the traditional artist in upholding pillars when he/she works is always preceded by a conviction against three things simultaneously. The first is the belief in the instrumental, utilitarian, and the wigati valuesof an artistic object that has been settled in cultural discourses. The second is the belief in knowledge he/ she has, in the form of models and concepts to be worked out and expressed; its form is discourse and artistic forms that have been entrenched. The third is the belief in the instrumentalvalue of the methods to realize the artwork that has developed into entrenchedartistic discourses. The reasoning is very simple, soits plot can be described as shown in Figure 7.

Beliefs, models, concepts, and methods of implementation, models and concepts for traditional artists are always present simultaneously, preceding the will to work. The artists will not develop the will to work when he/she does not have enough knowledge about the models, concepts, and methods of application of the model and the concept thoroughly. The will to work for him/her can not be separated from all the elements of pillars as a foothold in the work. All the elements have been a repertoire of knowledge which has been kasariro (internalized) within the self of a traditional artists. They have manifested as matter of practical knowledge and theoretical knowledge acquired in cognitiveandpsychomotor levels.

\subsection{Contemporary Reasoning in the Creation of Contemporary Art}

Contemporary artwork is created by a contemporary artist. A contemporary artist is an artists who demands him/ herself to behave and produce work that is original, unique, and typical. He or shedoes not want the work created is equal or has similar elements to other artist's work(s). Originality, uniqueness, and typicality is a target which is constantly sought for. The three are developed in the form and the content of artwork to achieve positive results from the contact of his/her thought steadily and a worldwide phenomenon when he/she develops the model and the concept of his/her works. The steadythough contact, then, leads toa stable method, which is eventually able to facilitate the working of the models and concepts to be present in the empirical reality and have symbolic meaning in the form of an artwork. 


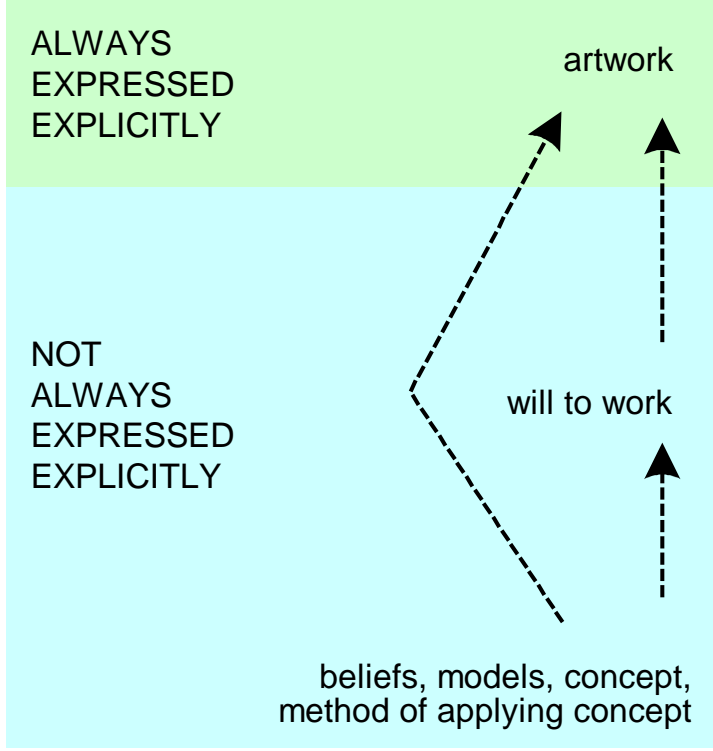

Figure 7. A reasoning tendency in pillars of traditional art creation (Sunarto, 2014b: p. 81).

Setting up pillars in an artwork having the original, unique, and typicalartistic construction is not easy. That is why many contemporary artist starts to work from a zero reasoning. That is, he/she startsprocessing a work from the will to work. When he wishes to create an artworks, he intentionally emptied himself from various matters relating to the experiences and artistic vocabularies existing from the past.

Unfortunately, ex nihilo nihil fit, emptiness will only give nothing. Creating works from zero point is essentially impossible. Such conditionis fully awared by contemporary artists. Despite of the awareness, strangely returning to zero isalways fighted for. Therefore, the self-emptying efforts are eventually interpreted as a free space that stimulates the widest possibilities for the presence of paradigmatic elements. The free space is space of possibilityto enter and explore new experiences. Typically, coming into the possibility space is done by an artist creator byexploiting logics and intuition to percieve and to process the perception, intellectual and intuitive reactions to various latest phenomena. This is critical to find special substances behind the phenomenon.

The reasoning stems from the will to work. Then it is followed by giving a possibility space in him/herselves for exploring the widest by deploying the logics and the intuition. The exploration enables to disclose special substances. That is why, this contemporary reasoning may also be referred to the reasoning of possibility space orthe reasoning of zero point. The reasoning can be illustrated as shown in Figure $\mathbf{8}$.

Main target of this reasoning is the deployment of power to find a special substance. Through exploration efforts with the deployment of the reason and intuitionpower, the special substance is perceived and captured as models and concepts. Through them, special substance is reacted into a method for applying the model and the concept of significant (wigati) spiritual values.

Special substance in the creation of contemporary artworks is the source for the development of models and concepts in the imagination. It is the means and procedures for the development of methods in creating a work. Methods of model and concept application is finding artisticfacts imagined to be made into accidentals that will be attached to various substances. The selection ofaccidental realityis done based on arguments dialectically moving toward the primacy of significant spiritual values. The artwork in the symbolic form and meaning is an empirical form, as well as the reality of accidentals which are deliberately attached by the art creator on the substance and meanings deemed to have a function.

\section{Closing}

The study of art creation, in the context of the development of science and the development of art, is supported by three same pillars of the existence, namely 1 ) the process of an activity, 2) activities that proceed by the method, and 3) the implementation of the activities and methods directed to produce and express a systematic 


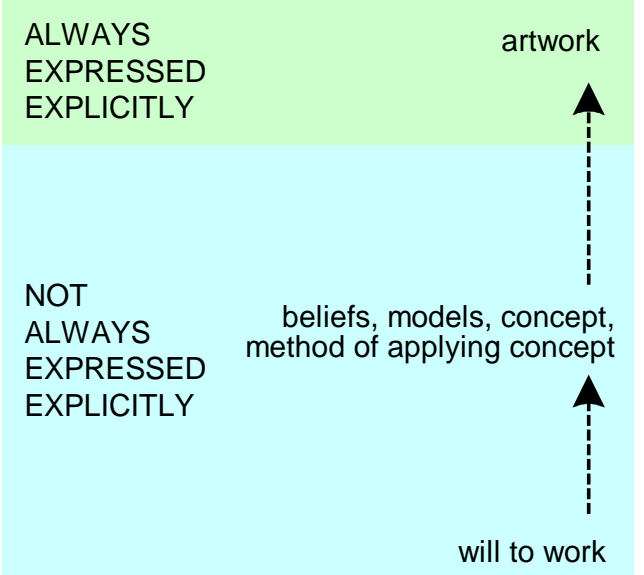

Figure 8. A reasoning tendency in the pillars of contemporary art creation (Sunarto, 2014b: p. 83).

knowledge. Knowledge in the study consists of practical, productive, and theoretical knowledges. Each exists in the interconnected propositions and is identified by prescriptions and descriptions. Proposition is a determinant of truth certainty and the impossibility of mistake. The propositions are manifestation of a number of given ideas as the basis as well as the product of the knowledges.

The study of artcreation uses a means of thought, order reasoning, and a set oflogically interconnected concepts in the form of connectionism. This is one of the ways or the models for the cognitive processes formed by means of distributing the elements of reasoningdialectic. Set of concepts is a framework that serves to understand, interpret, and explain the reality or to work values to be realized in the scientific work or artwork. A set of concepts in the research are called paradigm, whereas those in the creation of art are called pillars. The Javanesecall pillars as adeg-adeg.

The study of art creation in the context of sciencedevelopment is the effort of development of research capability to implement and to conduct a critical review of the science paradigm of art creation, using the material object of art creation activity. The important competence in the process is the capability of art creation to apply and to undertake a critical review on the pillars of art creation. It can be realized if it is supported by a reasoning reflected on the mastery and understanding of literature.

The reasoning on the study of art creation in the art discipline employes a variety of reasoning. It is oriented towards the establishment and the elaboration of the concept through an artistic proposition. An artist creating work of arts always has a concept. It means that, he/she is capable of delivering a statement and expressing the artistic intention. Reasoning in the discipline can not be separated from the subjective mental imagery. Therefore, subjectivism is the central reasoning in the study of art creation of art in the art discipline. It is the dominant pole constituing a basis of the conviction, the will to work, models, concepts, and methods to make a focus.

\section{References}

Ahimsa-Putra, H. S. (2008). Paradigma dan Revolusi Ilmu dalam Antropologi Budaya: Sketsa Beberapa Episode. Professor Inauguration Speechin the Faculty of Humanities University of Gadjah Mada, Yogyakarta, 10 November 2008.

Ahimsa-Putra, H. S. (2009). Paradigma Ilmu Sosial-Budaya: Sebuah Pandangan. Paper Presented at the Public Lectureon "Paradigma Penelitian Ilmu-Ilmu Humaniora”, Organized by the Linguistic Studies Program, Graduate School, Indonesian Education University, Bandung, 7 December 2009.

Bagus, L. (2005). Kamus Filsafat. Jakarta: PT Gramedia Pustaka Utama.

Friedel, F. J. (1943). The Formal Object of the Social Sciences. The American Catholic Sociological Review, 4, $16-24$. http://dx.doi.org/10.2307/3707926

Gazalba, S. (1977). Sistematika Filsafat: Pengantar Kepada Dunia Filsafat, Teori pengetahuan, Metafisika, Teori Nilai. Jakarta: Bulan Bintang.

Griffith, T. L. et al. (2003). Virtualness and Knowledge in Teams: Managing the Love Triangle of Organizations, Individuals and Information Technology. MIS Quarterly, 27, 265-287. 
Houde, R., \& Michael-Mullally, J. P. (1960). Philosophy of Knowledge: Selected Readings. Boston: Lippincott. Kemeny, J. G. (1961). A Philosopher Look at Science. New York: Van Nostrand Reinhold.

Klubertanz, G. P. (1955). Introduction to the Philosophy of Being. New York: Appleton-Century-Crofts.

Lachman, S. J. (1969). The Foundation of Science, Edisi Revisi Tahun (4th Print). New York: Vantage Press.

Peter, F. E. (1970). Greek Philosophical Terms: A Historical Lexicon. New York: New York University Press.

Sunarto, B. (2010). Epistemologi Karawitan Kontemporer Aloysius Suwardi. Dissertation, Faculty of Philosophy, University of Gadjah Mada.

Sunarto, B. (2013). Epistemologi Penciptaan Seni. Yogyakarta: Idea Press Yogyakarta.

Sunarto, B. (2014a). Konsepsi Studi Ilmu Penciptaan Seni. Paper Presented at the National Seminar on "Spirit of the Future: Art for Humanizing” in Frame of Indonesian Art Festival 8th, Yogyakarta, 27 September 2014.

Sunarto, B. (2014b). Pengetahuan dan Penalaran dalam Studi Penciptaan Seni. In S. Nugroho (Ed.), Prosiding Seminar Nasional Pengembangan Model Disiplin Seni. Surakarta: ISI Press.

Turner, D. (2004). Faith, Reason, and the Existence of God. Cambridge: Cambridge University Press. http://dx.doi.org/10.1017/CBO9780511617317

Warfield, J. N. (1976). Societal System: Planning, Policy and Complexity. New York: John Wiley \& Sons. 